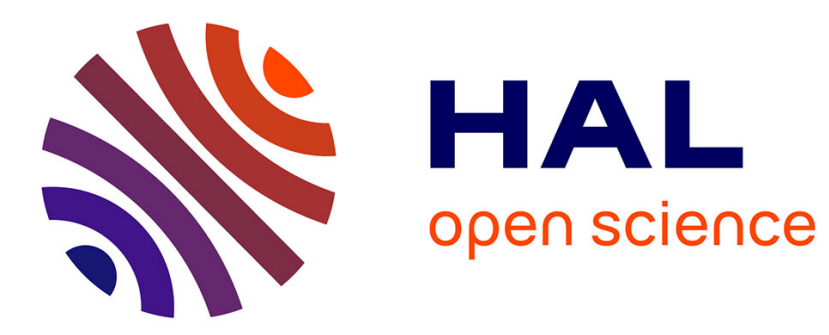

\title{
Total organic carbon dynamics in the Aegean Sea
}

Richard Sempere, Christos Panagiotopoulos, R. Lafont, B Marroni, France van Wambeke

\section{To cite this version:}

Richard Sempere, Christos Panagiotopoulos, R. Lafont, B Marroni, France van Wambeke. Total organic carbon dynamics in the Aegean Sea. Journal of Marine Systems, 2001. hal-02065006

\section{HAL Id: hal-02065006 https://hal.science/hal-02065006}

Submitted on 12 Mar 2019

HAL is a multi-disciplinary open access archive for the deposit and dissemination of scientific research documents, whether they are published or not. The documents may come from teaching and research institutions in France or abroad, or from public or private research centers.
L'archive ouverte pluridisciplinaire HAL, est destinée au dépôt et à la diffusion de documents scientifiques de niveau recherche, publiés ou non, émanant des établissements d'enseignement et de recherche français ou étrangers, des laboratoires publics ou privés. 
Sempéré, R., Panagiotopoulos, C., Lafont, R., Marroni, B., Van Wambeke, F., (2002) Total organic carbon dynamics in Aegean Sea. Influence of Black Sea inputs. Journal of Marine Systems 33-34, 335-364.

\title{
Total organic carbon dynamics in the Aegean Sea
}

\author{
R. Sempéré *, C. Panagiotopoulos, R. Lafont, B. Marroni, F. Van Wambeke \\ Laboratoire de Microbiologie Marine (CNRS/INSU, UMR 6117), Centre d'Océanologie de Marseille, \\ Université de la Mediterranée-Campus de Luminy, Case 907, Marseille Cedex 9, France
}

Received 14 February 2001; accepted 6 June 2001

\begin{abstract}
During the Mater oceanographic cruise, seawater samples were collected during September 1997 in the northern and southern parts of Aegean Sea and analyzed for total organic carbon (TOC) by using a high temperature catalytic oxidation method. Our results indicate that TOC concentrations decreased from the surface to deep waters from 52-128 to $48-56 \mu \mathrm{M} \mathrm{C}$ in the North and from 55-87 to $47-56 \mu \mathrm{M} \mathrm{C}$ in the South. Standing stocks of TOC in the upper $100 \mathrm{~m}$, ranged from 6300 to $9120 \mathrm{mmol} \mathrm{C} \mathrm{m}^{-2}$ in the North and from 6563 to $7483 \mathrm{mmol} \mathrm{C} \mathrm{m}^{-2}$ in the South. Basically, higher concentrations were observed in the North and particularly for waters where the signature of Black Sea water was more pronounced. From salinityTOC relationships, we estimated that TOC input from the Marmara and Black Sea to the Mediterranean Sea through the Dardanelles Strait varied from 1.6 to $23.7 \times 10^{10} \mathrm{~mol} \mathrm{C} \mathrm{year}^{-1}$. Our computations of TOC budget suggest that TOC inflow through Dardanelles Strait, is slightly lower than TOC input from Mediterranean rivers and from the atmosphere, whereas it is one order of magnitude lower than that reported for the Atlantic Ocean via the Gibraltar Strait. We also discuss the distribution of TOC in relation to bacterial production (BP) and associated bacterial carbon demand (BCD). Assuming a bacterial growth efficiency (BGE) of $0.30, \mathrm{BCD}$ in the upper $100 \mathrm{~m}$ was on average $18.1 \mathrm{mmol} \mathrm{C} \mathrm{m}^{-2} \mathrm{day}^{-1}$ in the North and $15.5 \mathrm{mmol} \mathrm{C}$ $\mathrm{m}^{-2}$ day $^{-1}$ in the South. Turnover times of excess TOC (calculated as the difference between surface water TOC and a mean value of TOC below $200 \mathrm{~m})$ in the upper $100 \mathrm{~m}$ were higher in the northern basin $(0.28-0.59$ years; av. 0.47 years) than in the central Aegean basin ( 0.20 years) and the southern basin $(0.20-0.36$ years; av. 0.28 years). These results may vary and need to be cautiously taken into account because of the uncertainties associated to the BGE. However, this study indicates that bacterial cycling of TOC is more effective in the South Aegean than in the North, which leads to a higher accumulation of TOC in North Aegean surface waters. (C) 2002 Elsevier Science B.V. All rights reserved.
\end{abstract}

Keywords: Total organic carbon; Bacterial consumption; Turnover time of TOC; Aegean Sea

\section{Introduction}

It is currently believed by marine biogeochemists, that dissolved organic carbon (DOC), which is the main reservoir of organic carbon in the Ocean is made

\footnotetext{
* Corresponding author. Tel.: +33-491-829050; fax: +33-491829051.

richard.sempere@mio.osupytheas.fr·(R. Sempéré).
}

up of several components including refractory material with turnover times of millennia, semi-labile material with turnover times of months to years and labile material with turnover times of hours to days (Williams and Druffel, 1987; Druffel et al., 1992; Bauer et al., 1992; Carlson and Ducklow, 1995a; Hansell et al., 1995). The labile components of DOC can be studied by measuring the DOC consumption by bacteria in laboratory experiments (Carlson and Ducklow, 1995b; Amon and Benner, 1996), 
whereas semi-labile and refractory DOC are usually determined through the examination of the DOC profiles throughout the water column (Wheeler et al., 1996; Hansell and Peltzer, 1998; Dafner et al., 2001). Since DOC is almost exclusively consumed by bacteria, concomitant study of bacterial production (BP) and DOC (or total organic carbon (TOC)) allow the estimation of DOC/TOC turnover time as well as potential $\mathrm{CO}_{2}$ respiration during the assimilation of dissolved organic matter.
A recent study (Roether et al., 1996) has indicated that the Aegean is currently the major contributor of warmer and more saline deep water for the eastern Mediterranean. The South Aegean is also the site of Cretan deep water (CDW) and Cretan intermediate water (CIW) (Theocharis and Georgopoulos, 1993) formation which ventilate the Levantine Intermediate water (LIW) and the layers below. Since biological and chemical processes taking place in the Aegean are probably affected by these environmental processes,

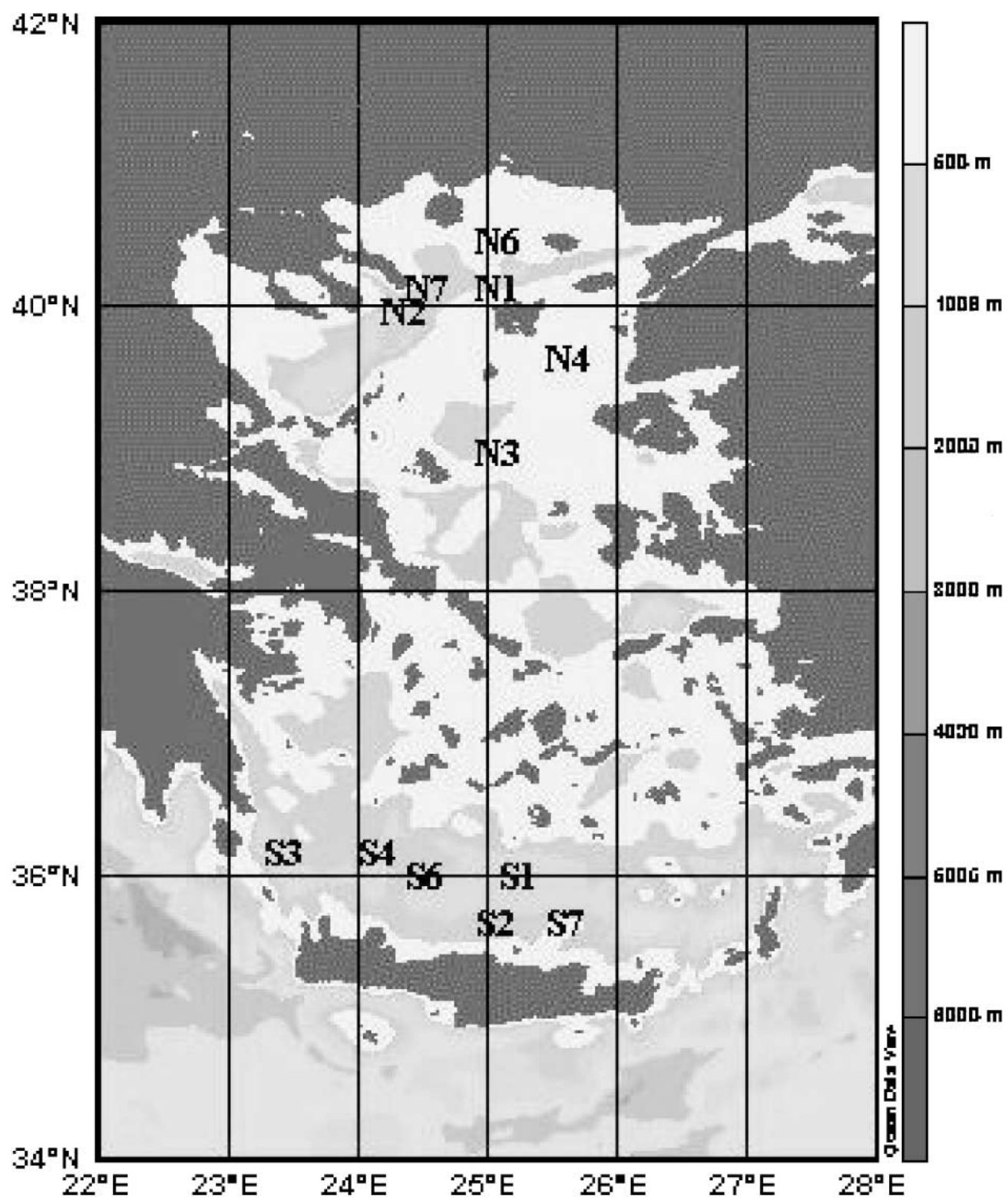

Fig. 1. Position of the sampling location during the Mater cruise (September 1997). Stations are distinguished by the latitude of $38^{\circ} \mathrm{N}$ are referenced as northern and southern station. Station $\mathrm{N}_{3}$ located in between is referenced as central station. 
there is a need to provide information on the TOC and associated bacterial cycling in the water column.

In the northern basin, fresh waters (Poulos et al., 1997) and mainly organic-rich brackish waters from the Black Sea (100-1000 $\mathrm{km}^{3}$ year ${ }^{-1}$ ) (Ünlüata et al., 1990; Latif et al., 1991) are injected in surface layer. Water exchange between the Mediterranean and the Black Sea occurs via the Dardanelles and the Bosphorus Straits and the Sea of Marmara located in between. A previous study has indicated that Black Sea surface inflow is usually higher than the outflow from the Aegean Sea towards the Marmara Sea (Polat and Tugrul, 1996). Although these authors have measured already TOC near the Dardanelles Strait, there are no published TOC data for the North and South Aegean Sea so far, and little is known about the influence of the Marmara and Black Sea on the biogeochemistry of the Aegean Sea.

In this paper, we describe the results of TOC measurements in terms of distribution and stock from the North to the South Aegean Sea in relation to BP. We also estimate the bacterial cycling of TOC in terms of turnover time and lability.

\section{Materials and methods}

\subsection{Field sampling}

Discrete seawater samples were taken from the R.V. Aegaeo at a series of stations from the South to the North of the Aegean Sea between 12 and 24 of
September 1997 (Fig. 1; Table 1). The stations in the South Aegean $\left(\mathrm{S}_{1}-\mathrm{S}_{4}, \mathrm{~S}_{6}-\mathrm{S}_{7}\right)$ can be considered as oligotrophic (Lykousis et al., 2002) comprising different water masses such as traces of Atlantic water, LIW and eastern Mediterranean Deep water (Klein et al., 1999 and references therein). By contrast, the North Aegean Sea is under the influence of Black Sea waters entering through the Bosphorus and Dardanelles Straits (Theocharis and Georgopoulos, 1993), which are known as the Turkish Strait system (Polat and Tugrul, 1996 and references therein).

A CTD rosette system (Seabird) equipped with 12-1 Niskin bottles was used. Stations were chosen to cover a variety of waters from southern to northern Aegean Sea near the Dardanelles and Bosphorus Straits. Samples were not filtered and were drawn as soon as possible after the rosette sampler was retrieved (either first or immediately following the gas samples). The 10 -ml samples were collected in duplicate in precombusted $\left(450{ }^{\circ} \mathrm{C}, \sim 6 \mathrm{~h}\right)$ glass vials. All vials were rinsed three times with the respective sample water before filling to the appropriate volume and then poisoned by addition of $\mathrm{HgCl}_{2}\left(10 \mathrm{mg} \mathrm{1^{-1 }}\right.$ final conc.).

Immediately after filling, the vials were closed with Teflon-lined screw caps and stored in the dark. Analytical work began 2 weeks after sample collection. We found that storage of seawater in pre-combusted glass vials closed with lined screw caps may give rise to higher TOC concentrations of $5 \pm 3 \mu \mathrm{M} \mathrm{C}(n=10)$ than seawater stored in flame-sealed precombusted

Table 1

Stations sampled during the Mater 2 cruise

\begin{tabular}{|c|c|c|c|c|c|}
\hline & Station I.D. & Date & Latitude $\left({ }^{\circ} \mathrm{N}\right)$ & Longitude $\left({ }^{\circ} \mathrm{E}\right)$ & Depth (m) \\
\hline \multirow[t]{6}{*}{ South } & $\mathrm{S} 1$ & 12 September 1997 & 36.04 & 25.17 & 1000 \\
\hline & $\mathrm{S} 2$ & 15 September 1997 & 35.44 & 25.06 & 1500 \\
\hline & S3 & 10 September 1997 & 36.00 & 23.53 & 1100 \\
\hline & $\mathrm{S} 4$ & 10 September 1997 & 36.15 & 24.06 & 850 \\
\hline & S6 & 13 September 1997 & 36.00 & 24.41 & 1295 \\
\hline & S7 & 14 September 1997 & 35.40 & 25.42 & 1295 \\
\hline \multirow[t]{6}{*}{ North } & N1 & 21 September 1997 & 40.14 & 25.12 & 700 \\
\hline & $\mathrm{N} 2$ & 22 September 1997 & 40.04 & 24.36 & 970 \\
\hline & N3 & 19 September 1997 & 39.13 & 25.00 & 700 \\
\hline & N4 & 20 September 1997 & 39.47 & 25.31 & 100 \\
\hline & N6 & 23 September 1997 & 40.34 & 25.08 & 100 \\
\hline & N7 & 23 September 1997 & 40.16 & 24.50 & 730 \\
\hline
\end{tabular}


glass ampoules. Results presented here are not corrected from such possible contamination.

\subsection{HTCO analysis}

The Shimadzu instrument used in this study was the commercially available model TOC-5000 total carbon analyser with a quartz combustion column in the vertical position filled with $1.2 \% \mathrm{Pt}$ on silica pillows with an approximate diameter of $2 \mathrm{~mm}$ (Cauwet, 1994). Several aspects of our modified unit have already been described (Yoro et al., 1999; Dafner et al., 1999, 2001). Briefly, the furnace temperature was maintained at 680 ${ }^{\circ} \mathrm{C}$ and the effluents passed through a mercury trap (gold wire) to remove mercury (Ogawa and Ogura, 1992). A magnesium perchlorate water trap was added to the system located before the halogen scrubber, in addition to an in-line membrane filter and the nondispersive infrared $\mathrm{CO}_{2}$ detector. Prior to analysis, subsamples were acidified with $10 \mu \mathrm{l}$ of $85 \% \mathrm{H}_{3} \mathrm{PO}_{4}$ to $\mathrm{pH} \sim 2$ and sparged for $10 \mathrm{~min}$ with $\mathrm{CO}_{2}$-free pure air to remove inorganic carbon as $\mathrm{CO}_{2}$.

TOC contamination from the preservation reagent and from the $\mathrm{H}_{3} \mathrm{PO}_{4}$ was below the detection limit. During the sparging procedure, we followed the recommendations of J.H. Sharp (University of Delaware), i.e., care was taken that during sparging of each sample, seawater did not overflow from the vials. This condition was possible at a gas flow rate of $40 \mathrm{ml} \mathrm{min}^{-1}$. One-hundred-microliter injections were repeated three to four times for each sample, the analytical precision of the procedure being within $3 \%$ on average. Some variability in values from two different vials gives rise to a lower overall precision (10\%). Prior to analyses of standards and samples, the catalyst bed was 'conditioned' by injecting $100 \mu \mathrm{l}$ of acidified and sparged water from a Millipore Milli-Q Plus ${ }^{\circledR}$ system, until the lowest stable integrated area was obtained. To stabilize values for the blank, the catalyst was pre-treated by washing in $1 \% \mathrm{HCl}$ and gently rinsed with Milli-Q water, and dried in a furnace at a temperature of about $450{ }^{\circ} \mathrm{C}$ for $10-15 \mathrm{~min}$.

\subsection{Calibration of the instrument}

Standardisation was carried out every day using potassium hydrogen phthalate (Kanto Chemical Company) dissolved in Milli-Q water (three concentra- tions) prepared just before sample analyses. The instrument response factor, measured as the slope of the standard added to Milli-Q water $\left(r^{2}>0.999\right.$ for 19 runs), remained relatively constant and reproducible over the time of the analysis. Calibration curves have exhibited little difference in the slope (av. slope: $5997 \pm 309$ area units, $n=19$ ) and intercept (av. intercept: $967 \pm 315$ area units, $n=19$ ). The accuracy and the system blank of our instrument were determined by analysis of the Deep Atlantic Water (DAW) reference and low carbon water (LCW) from ampoules provided by J.H. Sharp. Average LCW area units were $764 \pm 242(n=19)$. The average DOC concentrations were $45 \pm 1 \mu \mathrm{M} \mathrm{C}, n=19$ in the DAW reference. TOC concentrations in samples were calculated by averaging all replicate injections of samples, subtracting the LCW average as the total blank and dividing by the slope of the standardisation curve.

\section{Results}

\subsection{Hydrography}

In the South and North Aegean Sea, the temperature-salinity profiles indicated highly saline water masses (salinity $\sim 39$ ) below $50 \mathrm{~m}$ in depth. Temperature and salinity which are described in details in Lykousis et al. (2001), confirmed previous observations indicating that the North Aegean consists essentially of three layers, including low salinity waters with a high percentage of Black Sea waters in the surface layer, highly saline and warm waters of Levantine origin (LIW) between 100 and $400 \mathrm{~m}$, and very dense North Aegean Deep waters (NAGDW) in the bottom layer of each sub-basin. This study clearly highlighted the occurrence of a shallow layer formed by saline waters coming from the South Aegean and Black Sea waters exiting from the Dardanelles Strait (Lykousis et al., 2002). This trend is particularly clear at St. $\mathrm{N}_{1}-\mathrm{N}_{2}$, and St. $\mathrm{N}_{4}-\mathrm{N}_{7}$. Surface salinity at station $\mathrm{N}_{3}$ indicates that there is little influence of Black Sea waters in this region. Consequently, in this article, this station will be considered as a central station and not as a North Aegean station.

Autotrophic biomass in the $0-100-\mathrm{m}$ layer was higher in the North eastern Aegean Sea $\left(\left[\mathrm{N}_{2}\right.\right.$ and $\left.\mathrm{N}_{4}\right]$ : 
$134 \mathrm{mmol} \mathrm{C} \mathrm{m}{ }^{-2}$ ) than in northern Aegean Sea (89 $\mathrm{mmol} \mathrm{C} \mathrm{m}{ }^{-2}$ ) and in the Southern Aegean Sea (54 mmol C m${ }^{-2}$ ) (Siokou-Frangou et al., 2002). In September, most of the autotrophic carbon biomass (ca. $80 \%)$ and primary production $(75 \%)$ in both basins were due to small-sized cells $(<3 \mu \mathrm{m})$ indicating that most of the fixed carbon flows through the microbial food web (Siokou-Frangou et al., 2002). Bacteria represent $59-69 \%$ of total heterotrophs whose stocks were higher in the southern Aegean Sea $(211 \mathrm{mmol} \mathrm{C}$ $\mathrm{m}^{-2}$ ) than in the North Aegean Sea (159-177 mmol C $\mathrm{m}^{-2}$ ) (Siokou-Frangou et al., 2001). Bacterial production in the $0-100-\mathrm{m}$ layer was higher in the North (3.90-7.02 $\mathrm{mmol} \mathrm{C} \mathrm{m}^{-2}$ day $^{-1}$; av. $5.43 \mathrm{mmol} \mathrm{C}$ $\mathrm{m}^{-2}$ day $^{-1}$ ) than in the South Aegean (3.89-6.30 mmol C m ${ }^{-2}$ day $^{-1}$; av. $4.65 \mathrm{mmol} \mathrm{C} \mathrm{m}^{-2}$ day $^{-1}$ ) (Christaki et al., 1999). Highest bacterial production was found at St. $\mathrm{N}_{4}$ where salinity was also lowest $(S=34.4$ at $5 \mathrm{~m})$. Bacterial to primary production ratio (BP/PP) was found to be higher in North Aegean (0.32) than in the South Aegean (0.23) (Siokou-Frangou et al., 2002).

\subsection{TOC distribution}

A composite of TOC profiles at the stations sampled down to the bottom is presented in Fig. 2. Profiles show a net decrease of TOC concentration

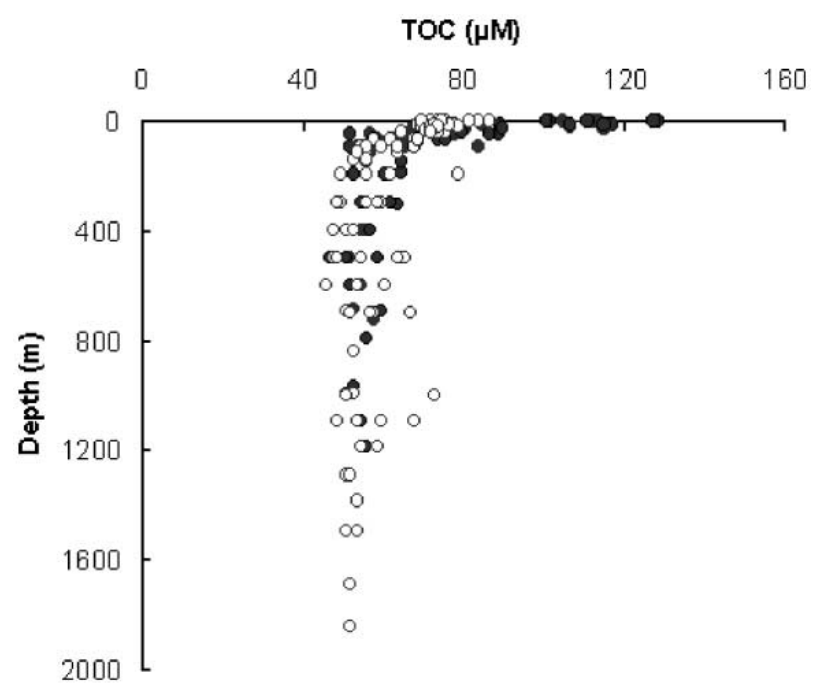

Fig. 2. Composite of deep vertical profiles of TOC ( $\mu \mathrm{M} \mathrm{C})$ at 12 stations in North (closed circles) and South Aegean Sea (open circles).
Table 2

Depth integrated carbon stocks $\left(\mathrm{mmol} \mathrm{C} \mathrm{m}^{-2}\right)$ in the upper $0-100$ $\mathrm{m}$ in the Aegean Sea

\begin{tabular}{|c|c|c|}
\hline Station I.D. & $\mathrm{TOC}\left(\mathrm{mmol} \mathrm{C} \mathrm{m}{ }^{-2}\right)$ & Salinity ranges \\
\hline N1 & 9020 & $34.7-38.8$ \\
\hline N2 & 8165 & $35.5-38.9$ \\
\hline N3 & 6300 & $38.9-39.1$ \\
\hline N4 & $5868^{\mathrm{a}}$ & $34.4-39.1$ \\
\hline N6 & 8410 & $34.9-38.9$ \\
\hline N7 & 9120 & $34.8-38.7$ \\
\hline S1 & 6563 & $39.1-39.4$ \\
\hline $\mathrm{S} 2$ & 7483 & $39.1-39.4$ \\
\hline S3 & 6960 & $38.6-39.3$ \\
\hline S4 & 6970 & $38.7-39.2$ \\
\hline S6 & 6823 & $39.1-39.4$ \\
\hline S7 & 7103 & $39.0-39.4$ \\
\hline
\end{tabular}

with depth (particularly in the North Aegean). Except for one cast at St. $\mathrm{S}_{2}$, which showed high TOC concentrations between 200 and $1000 \mathrm{~m}(60-79 \mu \mathrm{M}$ $\mathrm{C}$; av. $69 \mu \mathrm{M} \mathrm{C}$ ), TOC concentrations were significantly elevated in the upper $100 \mathrm{~m}$ compared to underlying waters. The concentrations of TOC in the intermediate and deep water (below $100 \mathrm{~m}$ ) were $47-$ $56 \mu \mathrm{M} \mathrm{C}$ in the North and $48-66 \mu \mathrm{MC}$ in the South. TOC in surface waters $(0-100 \mathrm{~m})$ ranged from 52 to $128 \mu \mathrm{M} \mathrm{C}$ in the North and from 55 to $87 \mu \mathrm{M} \mathrm{C}$ in the South (Fig. 2). Highest surface TOC concentrations were observed at St. $\mathrm{N}_{7}$ which is clearly under the influence of the Black Sea, as it is suggested from salinity data (Table 2). The TOC stocks in the upper $100 \mathrm{~m}$ ranged from 6300 to $9120 \mathrm{mmol} \mathrm{C} \mathrm{m}^{-2}$ in the North and from 6563 to $7483 \mathrm{mmol} \mathrm{C} \mathrm{m}^{-2}$ in the South Aegean (Table 2). In the North Aegean, higher TOC stocks in surface waters were observed for lower seawater salinities. Consequently, the stocks are much higher in the layers whose proportion of brackish waters is more elevated. Clearly, the major feature of the integrated TOC pool is a South-North contrast in surface which might be related to Black Sea inflow in the North Aegean.

Fig. 3 shows several features of TOC and BP vs. salinity relationship. Basically, in the South Aegean, correlation between salinity and TOC is only marginally significant $(r=0.31 ; p=0.045 ; n=41)$ indicating that TOC concentration variations were mainly due to biological processes such as production from organisms and bacterial assimilation. In contrast, in the 

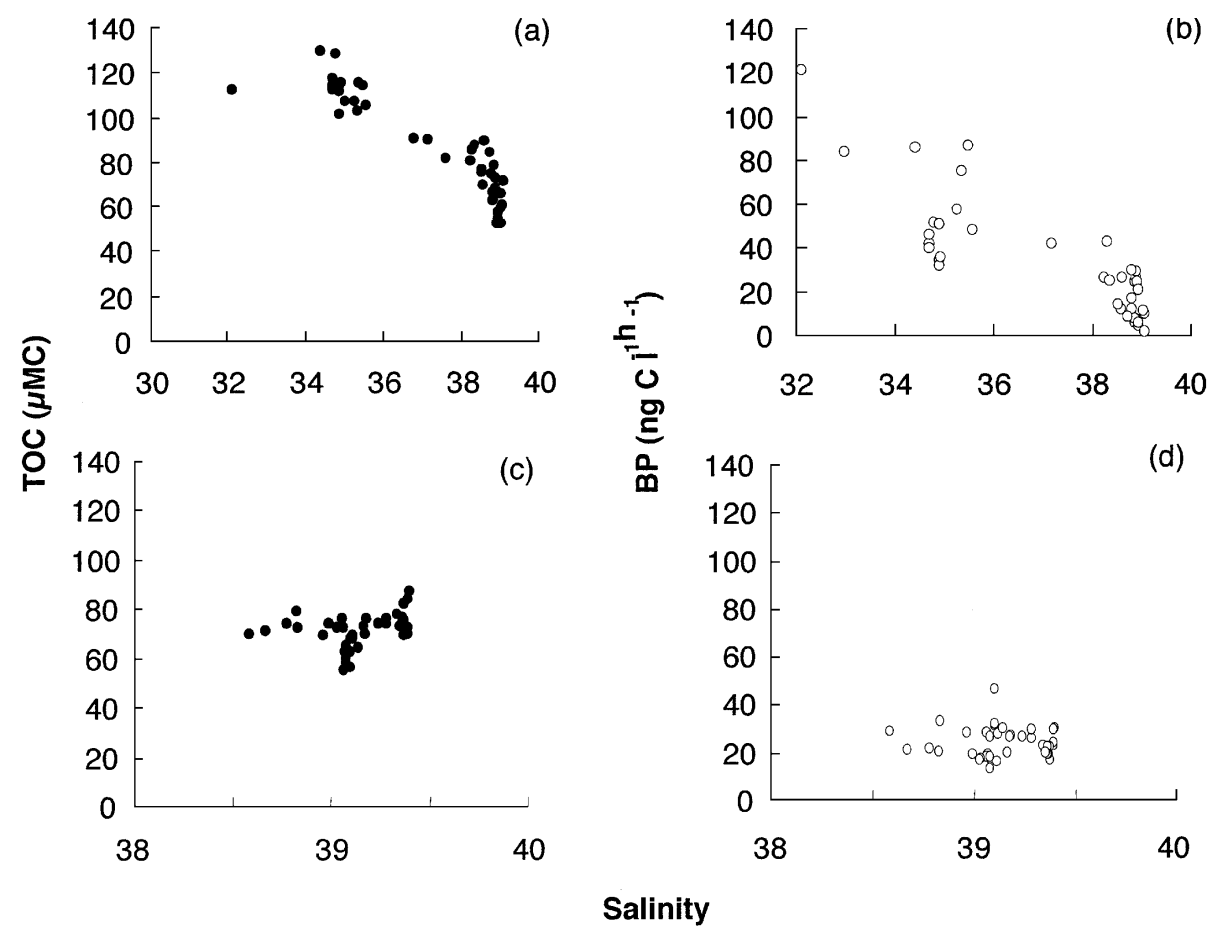

Fig. 3. TOC and bacterial production (BP) as a function of salinity in North Aegean Sea (a and b) and South Aegean Sea (c and d). Note the different salinity scales between $(a-b)$ and $(c-d)$.

North Aegean, there is a significant correlation between TOC and salinity

TOC $=-10.78 S+484.78, \quad r=0.91$

$p=2.0 \times 10^{-18} ; \quad n=45$.

In other words, TOC profiles always show a gradient coinciding with the halocline for all the stations studied, which is consistent with Polat and Tugrul (1996). BP had a similar trend to that of TOC (Fig. 3a and b) showing that higher bacterial productions were found for higher TOC concentrations and indicating that Black Sea inputs stimulate bacterial activity.

\section{Discussion}

High TOC concentrations usually found in surface waters may be attributed to excretion by healthy algae, slow rates of degradation, elevated zooplanktonic activity and external inputs (Wheeler et al., 1996 and references therein) as well as organic particle decomposition (Sempéré et al., 2000a). These biological processes may probably explain the TOC distribution in the South Aegean. However, in the surface waters of the northern basin, highest concentrations $(>100 \mu \mathrm{M} \mathrm{C})$ were found for the less saline surface waters $(S=34-39)$. Since salinity data is evidenced by the signature of Black Sea water, our results indicate that Black Sea waters via the Marmara surface water output are a source of TOC for Aegean Sea. It is well known that Black Sea coastal waters transported towards the Bosphorus regions are drastically polluted by large inputs of nutrients and organic matter via riverine and waste water discharges (Mee, 1992). Moreover, the polluted Black Sea surface inflow, before spreading into the upper layer of the Marmara Sea, is further contaminated by waste discharges into the Bosphorus from the city of Istanbul by numerous industries and six million people (Polat and Tugrul, 1996 and references therein). Moreover, our study indicates that surface TOC concentrations are regulated by biological activities in the southern basin and by both biological activity and external input from the Black Sea in the northern basin.

Polat and Tugrul (1996) showed that on an annual basis, the salinity of Marmara Sea water entering into the Aegean through the Dardanelles Strait ranged from 
23 to ca. 30. Such values incorporated into Eq. (1) give rise to TOC concentrations of the Black Sea waters inflow (in the Aegean Sea) ranging from 161 to $237 \mu \mathrm{M}$ C. Assuming a flux of Black Sea waters in the North Aegean ranging from 100 to $1000 \mathrm{~km}^{3}$ year ${ }^{-1}$ (Latif et al., 1991), we estimated TOC export of 1.6$23.7 \times 10^{10} \mathrm{~mol} \mathrm{C}$ year $^{-1}$, which is consistent with that proposed $\left(12 \times 10^{10} \mathrm{~mol} \mathrm{C}\right.$ year $\left.^{-1}\right)$ by Polat and Tugrul (1996) after a seasonal study. These estimates are low when considering the Mediterranean standing crop of TOC $\left(247 \times 10^{12} \mathrm{~mol} \mathrm{C}\right)$ (Sempéré et al., $2000 \mathrm{~b}$ ), and are one order of magnitude lower than the Atlantic Ocean inputs through the Gibraltar Strait; (Copin-Montégut, 1993; Dafner et al., 2001), but in the same order of magnitude than rivers (Copin-Montégut, 1993; Ludwig et al., 1998; Sempéré et al., 2000b) and atmospheric inputs to the whole Mediterranean Sea (Loyé-Pilot et al., 1992; Copin-Montégut, 1993).

Our results indicated that below $200 \mathrm{~m}$, TOC concentrations were similar at the northern and southern stations (Fig. 2). Average of TOC data below 200 $\mathrm{m}$ is about $54 \mu \mathrm{M} \mathrm{C}$. Interestingly, intercept calculation taken from the North-TOC vs. bacterial production relationship indicates that TOC is close to 50 $\mu \mathrm{M} \mathrm{C}$ for negligible bacterial production. Such TOC value is probably similar to refractory TOC. These estimates of refractory TOC are in reasonable agreement with that reported for various Mediterranean waters (ca. 50-75 $\mu \mathrm{M} \mathrm{C}$ ) of the Gulf of Lions (Cauwet et al., 1997; Yoro et al., 1997; Raimbault et al., 1999), the Ligurian Sea (Copin-Montégut and Avril, 1993), the Catalan-Balearic Sea (Gasol et al., 1998) of the Mediterranean basin. Lower DOC concentrations in deep waters $(38-52 \mu \mathrm{M} \mathrm{C})$ were recently measured in the western Mediterranean Sea by Doval et al. (1999) in the Catalan-Balearic Sea, by Dafner et al. (2001) in the Gibraltar Strait in Spring, and in the Alboran Sea (Sempéré et al., unpublished observations). Lower estimates of the refractory-DOC pool have been reported for the Atlantic (Thomas et al., 1995; Kähler and Koeve, 2001), Sargasso Sea (Carlson and Ducklow, 1995b), Pacific (Peltzer and Hayward, 1996), Southern (Kähler et al., 1997; Wiebinga and de Baar, 1998; Ogawa et al., 1999), and Northwestern Indian Oceans (Hansell and Peltzer, 1998).

Excess TOC was calculated using the mean value of TOC below $200 \mathrm{~m}(54 \mu \mathrm{M} \mathrm{C})$ as the refractory pool. Excess TOC in the upper $100 \mathrm{~m}$ (Fig. 4) accounted for $30-41 \%$ (av. 36\%) and for $18-24 \%$ (av. $22 \%$ ) of total-TOC in the upper $100 \mathrm{~m}$ at the stations sampled in North and South Aegean, respectively. The excess TOC accumulating in the South Aegean consists of semi-labile material produced through various biological processes, which turns
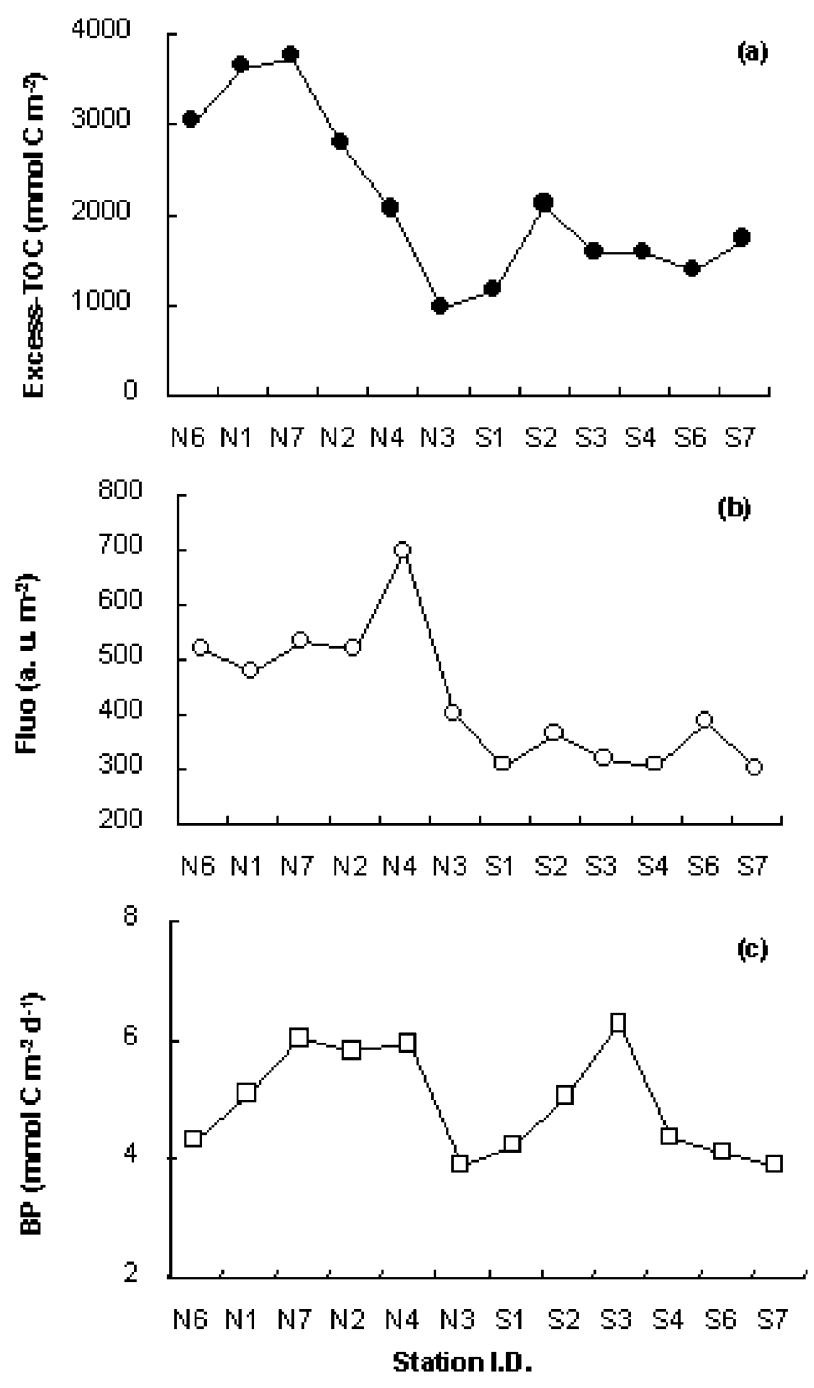

Fig. 4. Integrated excess TOC (a), integrated chlorophyll (b) inventories and integrated bacterial production (c) in the upper 0$100 \mathrm{~m}$ in North and South Aegean Sea. Integrated excess TOC $\left(\mathrm{mmol} \mathrm{C} \mathrm{m}{ }^{-2}\right)$ in surface water was calculated as the difference between discrete TOC in the upper layer and an average of TOC below $200 \mathrm{~m}$, the latter being considered as 'refractory TOC'. In the graphs, North Aegean stations are classified according to the Black Sea water influence (from the less saline to the more saline waters) estimated from the integrated salinity in the upper $100 \mathrm{~m}$ or in the upper $75 \mathrm{~m}$ (for St. $\mathrm{N}_{4}$ ). 
Table 3

Comparison of bacterial production (BP) and Excess TOC turnover time $(\tau)$ in the upper $0-100 \mathrm{~m}$ in the Aegean Sea

\begin{tabular}{lllll}
\hline Station I.D. & $\begin{array}{l}\text { BP }\left(\mathrm{mmol} \mathrm{C}^{-2}\right. \\
\left.\mathrm{m}^{-2} \text { day }^{-1}\right)\end{array}$ & $\begin{array}{l}\text { Excess } \\
\text { TOC }\end{array}$ & $\begin{array}{l}\text { Excess } \\
\text { TOC }\end{array}$ & $\begin{array}{l}\text { Excess } \\
\text { TOC }\end{array}$ \\
\cline { 3 - 5 } & & BGE $=$ & BGE $=$ & BGE $=$ \\
& & 0.30 & 0.23 & 0.14 \\
\hline $\mathrm{N} 1$ & 5.06 & 0.59 & 0.45 & 0.27 \\
$\mathrm{~N} 2$ & 5.82 & 0.39 & 0.30 & 0.18 \\
$\mathrm{~N} 3$ & 3.90 & 0.20 & 0.16 & 0.09 \\
$\mathrm{~N} 4$ & 5.93 & $0.28^{\mathrm{a}}$ & $0.22^{\mathrm{a}}$ & $0.13^{\mathrm{a}}$ \\
$\mathrm{N} 6$ & 4.31 & 0.57 & 0.44 & 0.27 \\
$\mathrm{~N} 7$ & 6.02 & 0.51 & 0.39 & 0.24 \\
S1 & 4.24 & 0.23 & 0.17 & 0.11 \\
S2 & 5.04 & 0.34 & 0.26 & 0.16 \\
S3 & 6.30 & 0.20 & 0.16 & 0.09 \\
S4 & 4.35 & 0.30 & 0.23 & 0.14 \\
S6 & 4.09 & 0.28 & 0.21 & 0.13 \\
S7 & 3.89 & 0.36 & 0.28 & 0.17 \\
\hline
\end{tabular}

Bacterial production (BP) was estimated by the ${ }^{3} \mathrm{H}$-leucine incorporation technique. For more details, see Christaki et al. (1999). $\tau$ were calculated using various values for bacterial growth efficiencies (BGE): 0.30 (Wheeler et al., 1996), 0.23 (del Giorgio et al., 1997) and 0.14 (Carlson and Ducklow, 1995b).

${ }^{\mathrm{a}} 0-75 \mathrm{~m}$.

over on a seasonal time scale. In the North Aegean, accumulating excess TOC consists very likely of both semi-labile TOC material produced in North Aegean and probably 'external' TOC introduced from the Black Sea and the Marmara Seas via the Dardanelles and the Bosphorus Straits.

In Fig. $4 \mathrm{a}-\mathrm{c}$, excess TOC accumulated in the upper $100 \mathrm{~m}$ is compared with corresponding measurements of phytoplankton biomass (deduced from CTD fluorescence data) and BP. Clearly, the elevated TOC concentrations show a clear trend with standing stocks of phytoplankton whereas it is less the case with BP. Moreover, these results suggest that Black Sea waters not only provide TOC but also induce development of phytoplankton in North Aegean.

Assuming a BGE of 0.30 (Wheeler et al., 1996), bacterioplankton carbon demand (BCD) in the upper $100 \mathrm{~m}$ was on average $18.1 \mathrm{mmol} \mathrm{C} \mathrm{m}^{-2}$ day $^{-1}$ in the North and $15.5 \mathrm{mmol} \mathrm{C} \mathrm{m}^{-2}$ day ${ }^{-1}$ in the South. Because bacteria are the main consumers of TOC, BP can be used to estimate the mean turnover time of excess TOC (Table 3). Average turnover time ranged from 0.28 to 0.59 years (av. 0.47 years) in the North ( 0.20 years in central Aegean: station $\mathrm{N}_{3}$ ), and from
0.20 to 0.36 years (av. 0.28 years) in the South Aegean. Lower turnover times were found at stations $\mathrm{N}_{3}$ and $\mathrm{N}_{4}$, both of which have the highest Black Sea water influence. These results are close $(0.13-1.22$ years) to turnover times reported for the Arctic (Wheeler et al., 1996). Like Aegean Sea, a part of TOC in Arctic might be attributed to riverine inputs. It is important to notice that excess TOC turnover times are likely to be inaccurate because of large uncertainties associated with the BGE. For instance, computation of our results using a BGE of 0.14 (Carlson and Ducklow, 1995b) would result in excess TOC turnover time of 0.22 years (av.) in the North and 0.13 years (av.) in the South, whereas the use of a BGE of 0.23 (del Giorgio et al., 1997) would give 0.36 years (av.) in the North and 0.22 years (av.) in the South. Nevertheless, whatever the BGE used, these results clearly indicate a more rapid bacterial cycling of TOC in the South than in the North of the Aegean Sea giving rise to an higher accumulation of TOC in the northern basin surface waters. This accumulated TOC might be mineralized as $\mathrm{CO}_{2}$ through bacterial respiration in deep or intermediate water in case of surface water convection, or alternatively in surface water elsewhere in the Aegean Sea.

\section{Acknowledgements}

We thank the crew of the R.V. Aegaeo for excellent service at sea as well as Dr. V. Lykousis chief scientist of September 1997-Mater cruise. Our special thanks go to Drs. R. Fukuda and B. Charrière for reading of the manuscript, to Dr. S. Newman for English correction and to Dr. J.H. Sharp who kindly provided the Deep Atlantic and low carbon water reference standards. This paper benefited from the constructive comments of the anonymous reviewers. This research was funded by the European Commission, MAST III Programme (Contract MAS3-CT96-0060). CP received a financial support from the Onassis foundation Greece.

\section{References}

Amon, R.M.W., Benner, R., 1996. Bacterial utilization of different size classes of dissolved organic matter. Limnol. Oceanogr. 41, $41-51$. 
Bauer, J.E., Williams, P.M., Druffel, E.R.M., 1992. ${ }^{14} \mathrm{C}$ activity of dissolved organic carbon fractions in the central North Pacific and Sargasso Sea. Nature (London) 357, 667-670.

Carlson, C.A., Ducklow, H.W., 1995a. Dissolved organic carbon in the upper ocean of the central equatorial Pacific Ocean, 1992: daily and finescale vertical variations. Deep-Sea Res. 42, 639656.

Carlson, C.A., Ducklow, H.W., 1995b. Growth of bacterioplankton and consumption of dissolved organic carbon in the Sargasso Sea. Aquat. Microb. Ecol. 10, 69-85.

Cauwet, G., 1994. HTCO method for dissolved organic carbon analysis in seawater: influence of catalyst on blank estimation. Mar. Chem. 47, 55-64.

Cauwet, G., Miller, A., Brasse, S., Fengler, G., Mantoura, R.F.C., Spitzy, A., 1997. Dissolved and particulate organic carbon in the western Mediterranean Sea. Deep-Sea Res., Part II 44, 769779 .

Christaki, U., Van Wambeke, F., Dolan, J.R., 1999. Monoflagellates (mixotrophs, heterotrophs and autotrophs) in the oligotrophic eastern Mediterranean. Standing stocks, bacterivory and relationships with bacterial production. Mar. Ecol. Prog. Ser. 187, 297-307.

Copin-Montégut, C., 1993. Alkalinity and carbon budgets in the Mediterranean Sea. Global Biogeochem. Cycles 7, 915-925.

Copin-Montégut, G., Avril, B., 1993. Vertical distribution and temporal variation of dissolved organic carbon in the North-West Mediterranean Sea. Deep-Sea Res. 40, 1963-1972.

Dafner, E.V., Sempéré, R., González, N., Gomez, F., Goutx, M., 1999. Cross-slope variations of dissolved organic carbon in the Gulf of Cadiz in relation to water dynamics (February 1998). Mar. Ecol. Prog. Ser. 189, 301-306.

Dafner, E., Sempéré, R., Bryden, H., 2001. Total organic carbon distribution through the Strait of Gibraltar in September 1997. Mar. Chem. 73, 233-252.

del Giorgio, P., Cole, P.A., Cimbleris, A., 1997. Respiration rates in bacteria exceed phytoplankton production in unproductive aquatic systems. Nature $385,148-151$.

Doval, M.D., Pérez, F., Berdalet, E., 1999. Dissolved and particulate organic carbon in the northwestern Mediterranean Sea. DeepSea Res., Part I 46, 511-527.

Druffel, E.R.M., Williams, P.M., Bauer, J.E., Ertel, J.R., 1992. Cycling of dissolved and particulate organic matter in the open ocean. J. Geophys. Res. 97, 15639-15659.

Gasol, J.M., Doval, M.D., Pinhassi, J., Calderón-Paz, J.I., GuixaBoixareu, N., Vaque, D., Pedrós-Alió, C., 1998. Diel variations in bacterial heterotrophic activity and growth in the north-western Mediterranean Sea. Mar. Ecol. Prog. Ser. 164, 107-124.

Hansell, D.A., Peltzer, E.T., 1998. Spatial and temporal variations of total organic carbon in the Arabian Sea. Deep-Sea Res., Part II 45, 2171-2193.

Hansell, D.A., Bates, N.R., Gunderson, K., 1995. Mineralization of dissolved organic carbon in the Sargasso Sea. Mar. Chem. 51, 201-212.

Kähler, P., Koeve, W., 2001. Marine dissolved organic matter: can its C:N ratio explain carbon overconsumption? Deep-Sea Res., Part I 48, 49-62.

Kähler, P., Bjørnsen, P.K., Lochte, K., Antia, A., 1997. Dissolved organic matter and its utilisation by bacteria during spring in the Southern Ocean. Deep-Sea Res., Part II 44, 341-353.

Klein, B., Roether, W., Manca, B.B., Bregant, D., Beitzel, V., Kavacevic, V., Luchetta, A., 1999. The large deep water transient in the eastern Mediterranean. Deep-Sea Res., Part I 46, $371-$ 414.

Latif, M.A., Ozsoy, E., Oguz, T., Unluata, U., 1991. Observations of the Mediterranean inflow into the Black Sea. Deep-Sea Res., Part I 38, 711-723.

Loyé-Pilot, M.D., Cauwet, G., Spitzy, A., Martin, J.M., 1992. Preliminary results on atmospheric wet deposition of organic carbon and nitrogen in Corsica. In: Martin, J.M., Barth, H. (Eds.), Water Pollution Research Report. EROS 2000, Third Workshop, vol. 28. Comm. Of the Eur. Comm, Brussels, pp. 519-532.

Ludwig, W., Amiotte-Suchet, P., Probst, J.L., 1998. Atmospheric $\mathrm{CO}_{2}$ consumption by continental erosion: present day controls and implications for the last glacial maximum. Glob. Planet. Change 16-17, 107-120.

Lykousis, V., Chronis, G., Tselepides, A., Price, B., Theocharis, A., Siojou-Frangou, I., Van Wambeke, F., Donovaro, R., Stavrakakis, S., Duineveld, G., Georgopoulos, D., Ignatiades, L., Souvermezoglou, A., Voutsinou, F., 2002. Major outputs of the recent multidisciplinary biogeochemical researches undertaken in the Aegean Sea. J. Mar. Syst. 33-34, 313-334 (this issue).

Mee, L.D., 1992. The Black Sea in crisis: the need for concerted international action. Ambio 21, 278-286.

Ogawa, H., Ogura, N., 1992. Comparison of two methods for measuring dissolved organic carbon in sea water. Nature (London) $356,696-698$.

Ogawa, H., Fukuda, R., Koike, I., 1999. Vertical distributions of dissolved organic carbon and nitrogen in the Southern Ocean. Deep-Sea Res., Part I 46, 1809-1826.

Peltzer, E.T., Hayward, N.A., 1996. Spatial and temporal variability of total organic carbon along $140^{\circ} \mathrm{W}$ in the equatorial Pacific Ocean in 1992. Deep-Sea Res., Part II 43, 1155-1180.

Poulos, S.E., Lindsay, F.S., Pates, J.M., 1997. Seasonal variability in sea surface oceanographic conditions in the Aegean Sea (eastern Mediterranean): an overview. J. Mar. Syst. 13, 225-244.

Polat, Ç., Tugrul, S., 1996. Chemical exchange between the Mediterranean and the Black Sea via the Turkish Straits. Bull. Inst. Oceanogr., Monaco, CIESM Sci. Ser. 2 SP 17, 167-186.

Raimbault, P., Pouvesle, W., Diaz, F., Garcia, N., Sempéré, R., 1999. Feasibility of using wet-oxidation and automated colorimetry for simultaneous determination of organic carbon, nitrogen and phosphorus dissolved in seawater. Mar. Chem. 66, 161-169.

Roether, W., Manca, B.B., Klein, B., Bregant, D., Georgopoulos, D., Beitzel, V., Kovacevic, V., Luchetta, A., 1996. Recent changes in eastern Mediterranean deep waters. Science 271, $333-335$

Sempéré, R., Yoro, S.C., Van Wambeke, F., Charrière, B., 2000a. Microbial decomposition of large organic particles in northwestern Mediterranean Sea. Mar. Ecol. Prog. Ser. 5 (198), $61-72$.

Sempéré, R., Charrière, B., Van Wambeke, F., Cauwet, G., $2000 \mathrm{~b}$. Carbon inputs of the Rhône River to the Mediterranean Sea: biogeochemical implications. Global Biogeochem. Cycles 14, $669-681$ 
Siokou-Frangou, I., Bianchi, M., Christaki, U., Christou, E., Giannakouru, A., Gotsis, O., Ignatiades, L., Pagou, K., Pitta, P., Psarra, S., Souvermozoglou, E., Van Wambeke, F., Zervakis, V., 2002. Carbon flow in the planktonic food web along a gradient of oligotrophy in the Aegean Sea (Mediterranean Sea). J. Mar. Syst. 33-34, 335-353 (this issue).

Theocharis, A., Georgopoulos, D., 1993. Dense water formation over the Samothraki and Limnos plateaux in the North Aegean Sea (Eastern Mediterranean Sea). Cont. Shelf Res. 13, 919-939.

Thomas, C., Cauwet, G., Minster, J.F., 1995. Dissolved organic carbon in the equatorial Atlantic Ocean. Mar. Chem. 49, 155169.

Ünlüata, U., Oguz, T., Latif, M.A., Öszoy, E., 1990. On the physical oceanography of the Turkish Straits. In: Pratt, L.J. (Ed.), The Physical Oceanography of the Sea Straits. Kluwer Academic Publishing, Dordrecht, pp. 25-60.

Wheeler, P.A., Gosselin, M., Sherr, E., Thibault, D., Kirchman, D.L.,
Benner, R., Whitledge, T.E., 1996. Active cycling of the organic carbon in the Central Arctic Ocean. Nature (London) 380, 697699.

Wiebinga, C.J., de Baar, H.J.W., 1998. Determination of the distribution of dissolved organic carbon in the Indian sector of the Southern Ocean. Mar. Chem. 61, 185-201.

Williams, P.M., Druffel, E.R.M., 1987. Radiocarbon in dissolved organic matter in the central North Pacific Ocean. Nature (London) 330, 246-248.

Yoro, S.C., Sempéré, R., Turley, C., Unanue, M.A., Durrieu de Madron, X., Bianchi, M., 1997. Cross-slope variations of organic carbon and bacteria in the Gulf of Lions in relation to water dynamics (north-western Mediterranean). Mar. Ecol. Prog. Ser. 161, 255-264.

Yoro, S.C., Panagiotopoulos, C., Sempéré, R., 1999. Dissolved organic carbon contamination induced by filters and storage bottle. Water Res. 33 (8), 1956-1959. 